\title{
Distribution of the cardiotoxin pavettamine in the coffee family (Rubiaceae) and its significance for gousiekte, a fatal poisoning of \\ ruminants
}

Daan Van Elst ${ }^{\mathrm{a}}$, Sarah Nuyens ${ }^{\mathrm{a}}$, Braam van Wyk $^{\mathrm{b}}$, Brecht Verstraete ${ }^{\mathrm{c}}$, Steven Dessein ${ }^{\mathrm{d}}$ and Els Prinsen ${ }^{\mathrm{a}}$

${ }^{a}$ University of Antwerp, Plant Growth and Development, University of Antwerp, Antwerp, Belgium.

${ }^{\mathrm{b}}$ H.G.W.J. Schweickerdt Herbarium, University of Pretoria, Pretoria 0002, South Africa

${ }^{\mathrm{c}}$ Plant Conservation and Population Biology, KU Leuven, Leuven, Belgium

${ }^{\mathrm{d}}$ National Botanic Garden of Belgium, Meise, Belgium

*corresponding author

Daan.VanElst@ua.ac.be

Tel. +323 2653714,

Fax. +323 2653417

Sarah.Nuyens@student.ua.ac.be

Braam.VanWyk@up.ac.za

Brecht.Verstraete@bio.kuleuven.be

Steven.Dessein@br.fgov.be

Els.Prinsen@ua.ac.be

\begin{abstract}
Gousiekte, a cardiac syndrome of ruminants in southern Africa, is caused by the ingestion of plants containing the polyamine pavettamine. All the six known gousiekte-causing plants are members of the Rubiaceae or coffee family and house endosymbiotic Burkholderia bacteria in their leaves. It was therefore hypothesized that these bacteria could be involved in the production of the toxin. The pavettamine level in the leaves of
\end{abstract}


82 taxa from 14 genera was determined. Included in the analyses were various nodulated and non-nodulated members of the Rubiaceae. This led to the discovery of other pavettamine producing Rubiaceae, namely Psychotria kirkii and Ps. viridiflora. Our analysis showed that many plant species containing bacterial nodules in their leaves do not produce pavettamine. It is consequently unlikely that the endosymbiont alone can be accredited for the synthesis of the toxin. Until now the inconsistent toxicity of the gousiekte-causing plants have hindered studies that aimed at a better understanding of the disease. In vitro dedifferentiated plant cell cultures are a useful tool for the study of molecular processes. Plant callus cultures were obtained from pavettamine-positive species. Mass spectrometric analysis shows that these calli do not produce pavettamine but can produce common plant polyamines.

\section{Keywords :}

Pavettamine, Gousiekte, Rubiaceae, Toxin, Polyamine

\section{Abbreviations}

\begin{tabular}{|c|c|}
\hline $\mathrm{UPLC}^{\mathrm{TM}}$ & Ultra Performance Liquid Chromatography \\
\hline MS/MS & tandem mass spectrometry \\
\hline IS & Internal Standard \\
\hline $\mathrm{BR}$ & the National Botanic Garden of Belgium \\
\hline PRU & the Manie van der Schijff Botanical Garden, University of Pretoria \\
\hline DSMZ & Deutsche Sammlung von Mikroorganismen und Zellkulturen GmbH \\
\hline TQD & Triple Quadrupole Detector \\
\hline $\mathrm{BEH}$ & Ethylene Bridged Hybrid \\
\hline MRM & Multiple Reaction Monitoring \\
\hline
\end{tabular}

\section{Introduction}

South Africa has a rich and varied flora that includes some 600 poisonous plants $[1,2,3]$. Plant poisoning of livestock is responsible for considerable economic losses in southern Africa (that part of the African continent south of the Kunene, Okavango and Zambezi Rivers). One of the six most important plant toxicoses in this region is gousiekte, causing the death of about 7000 head of livestock, mainly sheep, goats and cattle, each year $[1,4,5]$. Gousiekte (Afrikaans for "quick disease") is a cardiac syndrome of domestic ruminants caused by the ingestion of certain poisonous plants. The disease is characterized by sudden death four to eight weeks after the initial intake of toxic plants, 
usually without obvious prodromal symptoms. At present six plant species, all belonging to the Rubiaceae, are known with certainty to cause the disease: Vangueria pygmaea (syn. Pachystigma pygmaeum) [6], V. thamnus (syn. Pachystigma thamnus) [7], V. latifolia (syn. Pachystigma latifolium), Pavetta schumanniana [8], Pa. harborii [9] and Fadogia homblei (syn. Fadogia monticola) [4].

Research on gousiekte commenced in 1908 when Walker attempted to establish the cause of the disease [6]. After many earlier authors have failed in their attempts, Fourie and coworkers [10] succeeded in isolating the causal toxin. They demonstrated the presence of the gousiekte-inducing compound in Pavetta harborii, P. schumanniana, Vangueria pygmaea and Fadogia homblei. The chemical structure of the toxin was published in 2010 [11]. It is a polyamine and was named pavettamine after the genus Pavetta, of which two species have been identified to cause the disease. It was hypothesized that endosymbiotic bacteria could be involved in the production of the toxin due to the fact that all six gousiekte-causing plants house bacteria of the genus Burkholderia in their leaves $[12,13,14]$. At present it is not known whether the endosymbiont plays any role in the production of the poisonous compound. Analysis of in vitro cultures of the Fadogia homblei endosymbiont, however, did not reveal production of pavettamine [15].

In the past, studies aimed at proving the link between gousiekte and suspected plants met with considerable difficulties as a significant number of animal feeding experiments gave negative results $[10,13,16]$. The toxicity of the known gousiekte-causing plants is variable and diminishes during drying. Animals differ in their susceptibility to the toxin and the disease cannot be induced in small laboratory animals. Moreover, feeding experiments have to deal with a long latency period and the lack of premonitory signs [16]. An earlier experiment in which sheep were fed limited quantities of Fadogia homblei gave negative results. It was assumed that the dose employed at that time was too low since subsequent studies proved this plant to cause gousiekte [4]. Therefore it was suggested that any rubiaceous plant could only be discounted as a possible cause of gousiekte if subjected to extensive feeding experiments [13]. 
Many plants closely related to the six known gousiekte-causing species occur in southern Africa. The Rubiaceae or coffee family is the fourth most species-rich flowering plant family with more than 13000 species comprising about 600 genera [17]. The Rubiaceae is particularly well represented in humid tropical forests, with species diversity decreasing rapidly from the subtropics through the temperate regions to the poles $[17,18]$. In southern Africa alone there occur more than 30 species of Pavetta [19,20]. It would be helpful to determine if in any of these plants the toxic principle is present and in which order of magnitude. Other Rubiaceae, or even species from other plant families, might contain pavettamine, perhaps in a lower concentration, insufficient to cause gousiekte. Alternatively such plants may not be consumed in significant quantities by domestic ruminants. The isolation procedure for the toxin described by Fourie et al. [10] made it possible to chemically assay plants for their toxicity. However, this method does not quantify the concentration of pavettamine and, as the authors stated, the procedure is tedious. Recently, a mass spectrometry based method for the analysis of pavettamine was reported [15]. It allows detection and quantification of pavettamine in biological samples in a fast and sensitive manner without the need for large sample volumes. Hitherto, plants or plant fractions could only be assayed for toxicity by using ethically questionable biological trials [10].

The primary objective of the present study is to assess whether pavettamine is present in other plant species, including species that lack bacterial endosymbionts. To estimate the role of bacteria and plants in the production of the toxin, callus cultures of pavettaminepositive species were tested in their capacity to produce the toxin in the absence of bacteria.

\section{Results and Discussion}

\subsection{Pavettamine is present in other plants than the six known gousiekte-causing species}

The potential presence and concentration of pavettamine were determined through detection by tandem mass spectrometry after derivatization with benzoyl chloride and separation by ultra-performance liquid chromatography (UPLC ${ }^{\mathrm{TM}}$ ) [15]. The selected 
plants, 82 taxa from 14 genera, are from the Rubiaceae since gousiekte has invariably been associated with plants of this family [4,16]. Given the presumed link between gousiekte-causing species and endosymbiotic bacteria, nodulated species were of particular interest. Plant taxa, in which pavettamine was detected, are listed in Table 1.

Table 1: List of plant samples in which pavettamine was detected. Value in $\mathrm{nmol} / \mathrm{g}$ fresh weight $(*$ nmol/g dry weight) \pm St Error $(\mathrm{N}=5)$

\begin{tabular}{|c|c|c|}
\hline Plant name & Accession & Pavettamine \\
\hline Fadogia homblei ${ }^{\mathrm{a}, \mathrm{c}}$ & Wild collected & $296 \pm 47^{*}$ \\
\hline Pa. harborii ${ }^{\text {b }}$ & Wild collected & $1284 \pm 68^{*}$ \\
\hline Pa. schumanniana ${ }^{\mathrm{b}}$ & BR-20041430-66 & $230 \pm 18$ \\
\hline Pa. schumanniana ${ }^{\text {b }}$ & BR-20001942-57 & $1381 \pm 79$ \\
\hline Pavetta sp. ${ }^{\text {b }}$ & BR-20060123-38 & $4135 \pm 121$ \\
\hline Psychotria sp. ${ }^{b}$ & BR-20001933-48 & $4084 \pm 174$ \\
\hline Ps. kirkii ${ }^{\text {b }}$ & BR-19951273-22 & $3116 \pm 101$ \\
\hline Ps. kirkii ${ }^{\text {b }}$ & BR-20010513-92 & $551 \pm 21$ \\
\hline Ps. kirkii ${ }^{\text {b }}$ & BR-19761893 & $414 \pm 31$ \\
\hline Ps. kirkii ${ }^{\text {b }}$ & BR-20070328-58 & $1352 \pm 156$ \\
\hline Ps. kirkii ${ }^{\text {b }}$ & BR-19750521 & $3660 \pm 151$ \\
\hline Ps. kirkii ${ }^{\text {b }}$ & BR-20021203-15 & $3330 \pm 226$ \\
\hline Ps. kirkii ${ }^{\text {b }}$ & BR-20021526-47 & $1644 \pm 118$ \\
\hline Ps. kirkii ${ }^{\text {b }}$ & BR-20070330-60 & $2095 \pm 272$ \\
\hline Ps. kirkii ${ }^{\text {b }}$ & BR-20001946-61 & $2005 \pm 79$ \\
\hline Ps. kirkii var. hirtella ${ }^{\text {b }}$ & BR-20001036-24 & $8674 \pm 1124$ \\
\hline Ps. kirkii var. nairobiensis ${ }^{\text {b }}$ & BR-19981825-19 & $322 \pm 26$ \\
\hline Ps. kirkii var. tarambassica ${ }^{\text {b }}$ & BR-19536779 & $1396 \pm 219$ \\
\hline Ps. viridiflora ${ }^{\mathrm{b}}$ & BR-20070138-62 & $1256 \pm 49$ \\
\hline Ps. cf. kirkii ${ }^{\text {b }}$ & BR-20001943-58 & $5172 \pm 513$ \\
\hline Vangueria pygmaea $^{\mathrm{c}}$ & Wild collected & $374 \pm 13^{*}$ \\
\hline
\end{tabular}

${ }^{\mathrm{a}}$ value adopted from Van Elst et al. [15]

${ }^{\mathrm{b}}$ species with leaf nodules

${ }^{\mathrm{c}}$ species with non-nodulating bacterial endophytes

Two additional species were found to be positive for the toxin, namely Psychotria kirkii and Ps. viridiflora. The genus Psychotria was previously not linked to the aetiology of gousiekte. In fact, the six gousiekte-causing species all belong to the subfamily Ixoroideae, while the genus Psychotria is of the subfamily Rubioideae [14,21]. Two other accessions, one nodulated Psychotria and one nodulated Pavetta species also produce 
pavettamine. Psychotria is the world's third largest flowering plant genus and the largest in the Rubiaceae [17]. We were unable to detect pavettamine in any of the other genera tested. Considering the concentration of pavettamine detected in these plants, it appears that the Psychotria species produce pavettamine in higher amounts that the traditional gousiekte-causing plant species. However, it is known that the toxicity in these plants varies at different times of the year, as well as from year to year $[4,6,8]$. Toxicity apparently also varies according to locality, habitat and probably climatic conditions $[6,8]$. The conditions of the plants grown in the greenhouses of the National Botanic Garden of Belgium might not accurately correspond to in-field conditions. Furthermore, a threshold concentration of pavettamine in leaves has not been determined for causing the onset of the development of gousiekte.

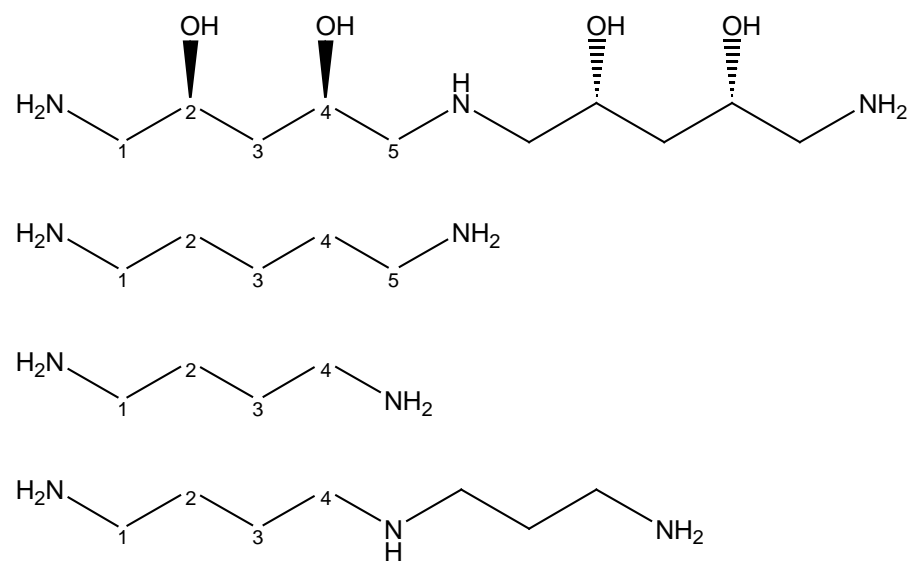

Figure 1: Comparison of the structures of pavettamine, cadaverine, putrescine and spermidine (from top to bottom).

The mass spectrometry method for the quantification of pavettamine as described by Van Elst et al. [15] allows the detection of several other important polyamines (diaminopropane, putrescine, cadaverine, spermidine, spermine and agmatine) alongside pavettamine in biological samples. Pavettamine certainly is an unusual polyamine and of the common plant polyamines most closely resembles cadaverine (see Figure 1), both having a carbon chain of five carbon atoms. Cadaverine is formed by the decarboxylation of lysine [22]. We did not detect cadaverine in many of the selected plants. However, we observed that all plants able to produced pavettamine can also produce cadaverine (see 
Table A.1, Supplementary files). At the moment, it is not known how pavettamine is synthesised. Given their structural similarity, cadaverine might be involved in the biosynthesis of pavettamine. Further studies should elucidate the possible relation between cadaverine and pavettamine.

\subsection{Gousiekte, a disease of southern Africa?}

In 1923, the Director of Veterinary Services in South Africa, Arnold Theiler, claimed that 'Gousiekte is a disease of South Africa' [23]. So far, gousiekte has been diagnosed in the northeastern part of South Africa, Botswana and southern Zimbabwe [4,24]. The geographical ranges of all six gousiekte-inducing plants overlap in the former Transvaal region, where most of the outbreaks happen [16]. However, the geographical range of these plants is thus much wider than the incidence of the poisoning syndrome [25]. We have detected pavettamine in several plants not collected from the area where gousiekte occurs. The two analyzed accessions of Pavetta schumanniana have an origin from Zambia and D.R. Congo. This indicates that the plants do produce the toxin throughout their geographical distribution range. The natural distribution of the Ps. kirkii varieties is from Gabon to Ethiopia and southern tropical Africa. Ps. viridiflora occurs naturally from Indo-China to Malaysia. It is peculiar that the gousiekte syndrome, which is of such economic importance in southern Africa, has not been encountered elsewhere in the world [4].

In the present study we have reported pavettamine to be present in members of the Rubiaceae hitherto not implicated in the disease. Recently, gousiekte has been diagnosed in wild African buffalo (Syncerus caffer) in the Mutirikwe Recreational Park southeast of Masvingo in Zimbabwe. Of the plants known to cause gousiekte, Pa. schumanniana occurs widely in the area [24]. It was reported that the buffalo herd, perturbed in their normal behavior, frequented the densely wooded areas of the park instead of the more open vegetation types. It is in these more wooded areas that $P a$. schumanniana is quite common. However, our results show that another plant present in the same area, Ps. kirkii, also produces pavettamine and consequently could cause gousiekte. It is the only widespread species of Psychotria in Zimbabwe, occurring in savannah and various types 
of woodland, often associated with rocky outcrops or termite mounds [26,27]. The intoxication of the buffalo reported by Lawrence et al. [24] could have possibly been caused by or aggravated by Ps. kirkii. It was commented previously that other toxic rubiaceous species might be ignored in areas where known gousiekte plants have been identified [13]. To date it is only possible to diagnose gousiekte post-mortem. Therefore, the prevention of intoxication remains the most important way to protect animals from gousiekte-causing plants $[1,16]$. It is therefore advantageous to know which species of plants contain the toxic pavettamine.

\subsection{Possible association between gousiekte and endophytic bacteria}

A possible link between endosymbiotic bacteria and gousiekte was postulated by Van Wyk et al. [13] following the discovery of non-nodulating bacterial endophytes in the leaves of gousiekte-inducing members of the genera Fadogia and Vangueria. In the two gousiekte-causing Pavetta species endosymbiotic bacteria are confined to distinct nodules in the leaf lamina [28]. Consequently, all gousiekte-causing plants contain bacterial endosymbionts in their leaves. DNA analysis of the bacterial endosymbionts in members of the Rubiaceae revealed that all these bacteria belong to the same genus, namely Burkholderia [12,14,29]. In addition, Verstraete et al. [14] analysed leaves from members of the genera Afrocanthium, Canthium, Keetia, Psydrax, Pygmaeothamnus and Pyrostria and found no presence of endosymbionts. Animal feeding studies confirmed that two of these non-bacteriophilous Rubiaceae species (Pygmaeothamnus zeyheri and P. chamaedendrum) are unable to cause gousiekte $[4,6]$. It was thus hypothesized that the endosymbiont might be involved in the production of the toxic compound [13,14]. For the plant Fadogia homblei, the endosymbiont was shown to be able to grow outside the host. However, it did not produce pavettamine in vitro when grown axenically [15]. The possibility remained that both partners in this plant-bacteria interaction are needed for the synthesis of the toxin or that unknown signals induce the synthesis of pavettamine in the bacteria. Our analysis shows that many plant species containing bacterial nodules in their leaves do not produce pavettamine (see Table A.1, Supplementary files). This is the case for Pavetta sp. (BR-20121181-83), Pa. radicans, Pa. bowkeri, Pa. zeyheri, Pa. lanceolata, Pa. gardeniifolia, Psychotria calva, Ps. humilis, Ps. kikwitensis, Ps. 
brachyanthoides, Ps. pumila var. pumila and Ps. verschuerenii var. reducta. It is therefore unlikely that the endosymbiont alone can be accredited for the production of the toxin. Significantly, all pavettamine positive plants remain bacteriophilous, since the species shown in this study to produce pavettamine are also nodulated.

\subsection{Callus cultures unable to produce pavettamine}

Until now the inconsistent toxicity of the gousiekte-causing plants have hindered studies that aimed at a better understanding of the disease. Basic knowledge on the plant physiological aspects of pavettamine is lacking [15]. Plant cell cultures are being widely used in scientific studies on the physiology, biochemistry and molecular biology of primary and secondary metabolism [30,31,32]. In vitro dedifferentiated plant cell cultures are more convenient for the study of cellular and molecular processes as they offer the advantage of a simplified model system for the study of plants and are more easily controlled compared to whole plant systems [32,33]. Callus was successfully initiated from sterilized leaf explants (not containing visible bacterial nodules) of two pavettamine positive species (Pavetta schumanniana, Psychotria kirkii var. tarambassica). Calli were maintained on growth medium and subcultured every 4 weeks. Sample of these callus cultures where analysed for their polyamine content and found to be unable to produce pavettamine. Mass spectrometric analysis shows that these calli can produce diaminopropane, putrescine, spermidine, spermine and agmatine on unsupplemented growth medium (see Table 2). Only the callus of Pa. schumanniana produced cadaverine, yet in very small amounts. At the moment there is no information on how pavettamine is being synthesized in the plant. Therefore, the growth media was supplemented with the common polyamine precursors: arginine, ornithine and lysine. Under these conditions, we could also not detect pavettamine in any of the calli cultures (see Table 2). Despite the low detection limit of the mass spectrometry method (reported 0.3 pmol in $6 \mu$ injected volume [15]), we could not detect any trace of pavettamine in the different callus samples. Addition of the polyamine precursors did have an effect on the concentrations of other polyamines analysed in the callus samples. For instance, the amount of cadaverine in the callus was higher when lysine was supplemented. A number of chemical and physical factors (such as media constitution, $\mathrm{pH}$, temperature and light) affect production 
Table 2: Polyamine concentrations determined in callus samples of Pavetta schumanniana and Psychotria kirkii var. tarambassica grown on unsupplemented and on polyamine-precusors supplemented medium. Value in nmol/g fresh weight \pm St Error $(\mathrm{N}=4)$ for putrescine (PUT), spermidine (SPD) and spermine (SPM); value in pmol/g fresh weight $\pm S t$ Error $(N=4)$ for diaminopropane (DAP), cadaverine (CAD), agmatine (AGM) and pavettamine (PAV).

\begin{tabular}{|l|l|l|l|l|l|l|l|}
\hline Pa. schumanniana & PUT & SPD & SPM & DAP & CAD & AGM & PAV \\
\hline Unsupplemented & $73.1 \pm 5.5$ & $24.3 \pm 1.2$ & $3.04 \pm 0.18$ & $347 \pm 10$ & $23 \pm 2$ & $486 \pm 47$ & ND \\
\hline + Arginine & $98.4 \pm 12.2$ & $34.5 \pm 2.2$ & $3.15 \pm 0.36$ & $273 \pm 16$ & ND & $828 \pm 117$ & ND \\
\hline + Lysine & $68.9 \pm 10.2$ & $26.6 \pm 1.8$ & $3.19 \pm 0.18$ & $218 \pm 19$ & $240 \pm 18$ & $563 \pm 85$ & ND \\
\hline + Ornithine & $81.9 \pm 13.3$ & $28.9 \pm 3.4$ & $2.85 \pm 0.14$ & $227 \pm 24$ & ND & $414 \pm 65$ & ND \\
\hline & & & & & & & \\
\hline $\begin{array}{l}\text { Ps. kirkii var. } \\
\text { tarambassica }\end{array}$ & PUT & SPD & SPM & DAP & CAD & AGM & PAV \\
\hline Unsupplemented & $64.7 \pm 4.8$ & $42.9 \pm 2.6$ & $8.71 \pm 0.70$ & $207 \pm 30$ & ND & $372 \pm 41$ & ND \\
\hline + Arginine & $81.9 \pm 3.2$ & $68.7 \pm 3.3$ & $9.70 \pm 0.35$ & $280 \pm 24$ & ND & $548 \pm 93$ & ND \\
\hline + Lysine & $68.5 \pm 6.1$ & $41.6 \pm 5.0$ & $8.92 \pm 0.29$ & $240 \pm 30$ & $217 \pm 17$ & $409 \pm 65$ & ND \\
\hline + Ornithine & $67.2 \pm 6.6$ & $54.5 \pm 3.9$ & $9.90 \pm 0.58$ & $216 \pm 34$ & ND & $415 \pm 42$ & ND \\
\hline
\end{tabular}

ND not detected

of secondary metabolites in plant cell cultures. Manipulation of cell culture conditions is one of the most fundamental approaches for optimization of culture productivity [31,32,34]. A yet unknown stimulus is probably responsible for the onset of pavettamine synthesis. Dedifferentiated cell cultures (i.e. callus or suspension) often produce low levels of secondary metabolites compared to differentiated cell cultures (i.e. roots or shoots) [32]. Future research into calli from pavettamine producing plants holds promise for a simplified model system in which different environmental factors, as well as the presence or absence of bacterial endophytes, can be tested for their influence in the production of the toxin.

\section{Experimental}

\subsection{Sample material}

Leaf sample material of the selected plants was collected from the living collections of the National Botanic Garden of Belgium (BR), the Manie van der Schijff Botanical Garden at the University of Pretoria (PRU) and during a field expedition to South Africa in February 2010. The most apical leaves on actively growing shoots were removed and immediately and individually frozen in liquid nitrogen. Leaf samples were stored at - 
$80^{\circ} \mathrm{C}$ until processed for mass spectrometric analysis. Polyamines are generally abundant in young, non-senescent organs, and decline to a lower concentration as organs age and senesce [35]. Previous analysis of the gousiekte-causing plant Fadogia homblei had shown that young leaves contain the highest concentration of pavettamine [15].

\subsection{Initiation of callus cultures}

Two plants, able to produce pavettamine, were selected for the creation of plant cell cultures: the known gousiekte-causing Pavetta schumanniana (BR-20001942-57) and Psychotria kirkii var. tarambassica (BR-19536779), shown in this study to produce pavettamine. Callus was initiated from pieces of leaf tissue cut from surface sterilized plants. Sterilization was achieved by immersing the explants in 70\% ethanol for $1 \mathrm{~min}$ followed by $10 \mathrm{~min}$ of 1\% hypochlorite solution. Sterilized explants were washed repeatedly with sterilized deionized water to remove the hypochlorite solution and subsequently placed on growth medium plates containing mediumP (http://www.dsmz.de/home.html). MediumP contains $20 \mathrm{~g} / \mathrm{l}$ sucrose, picloram $0.1 \mathrm{mg} / \mathrm{l}$ and Gamborg B5 medium. The explants were incubated in the dark at $23{ }^{\circ} \mathrm{C}$. Calli were formed readily and were subcultured every 4 weeks. Basic growth medium was supplemented with $0.1 \mathrm{mM}$ of the polyamine precursors L-arginine, L-lysine and Lornithine to elicit pavettamine production. Callus samples from unsupplemented and polyamine precursor supplemented medium were harvested after 21 days of growth at 23 ${ }^{\circ} \mathrm{C}$ in the dark. All chemicals used were obtained from Sigma Aldrich (Schnelldorf, Germany).

\subsection{Extraction and derivatization of polyamines}

The derivatization procedure was adopted from Van Elst et al. [15]. Briefly, polyamines were extracted by adding $1 \mathrm{ml}$ perchloric acid (5\%) per $100 \mathrm{mg}$ of powdered tissue. After incubation on ice for $60 \mathrm{~min}$, the homogenate was centrifuged (20 min, $20000 \mathrm{~g}, 4^{\circ} \mathrm{C}$ ). $250 \mu \mathrm{l}$ of this extract was mixed with $1.5 \mathrm{ml} 2 \mathrm{~N} \mathrm{NaOH}$ and $200 \mathrm{pmol}$ IS. The internal standard 1,7-diaminoheptane was obtained from Sigma Aldrich (Schnelldorf, Germany). The extracts were derivatized using $20 \mu$ l benzoyl chloride (20 min., room temperature). Benzoyl chloride was of reagent grade, >99\% purity A.C.S. (Sigma Aldrich). 
Benzoylated polyamines were extracted in $4 \mathrm{ml}$ diethyl ether. The aquous phase was discarded; the ether phase was washed with distilled water, collected and evaporated under a stream of nitrogen. Samples were stored at $-20^{\circ} \mathrm{C}$ until being redissolved in $80 \%$ ACN and transferred to inserts before injection in a UPLC ${ }^{\mathrm{TM}}$ MS/MS system. Acetonitrile (HPLC grade), water (HPLC grade) and ether were of VWR prolabo (Leuven, Belgium).

\subsection{Analysis of benzoylated polyamines by UPLC-MS/MS}

Chromatography and detection by mass spectrometry was performed using an ACQUITY UPLC $^{\mathrm{TM}}$ TQD system (Waters, Micromass, Ltd., Manchester, United Kingdom) equipped with electrospray ionization. Of the redissolved sample, $6 \mu \mathrm{l}$ (partial loop) was injected in an ACQUITY UPLC ${ }^{\mathrm{TM}}$ BEH C18 column (1.7 $\mu \mathrm{m}$ x $2.1 \mathrm{~mm}$ x $50 \mathrm{~mm}$, Waters) fitted with a VanGuard ${ }^{\mathrm{TM}}$ Pre-Column (2.1 mm x $5 \mathrm{~mm}$, Waters). The mass spectrometer was used in multiple reaction-monitoring mode (MRM). MRM transitions, cone, collision energy settings and chromatographic parameters are adopted from Van Elst et al. [15]. Masslynx NT version 4.1 (Waters) software was used to analyse the data.

\section{Acknowledgments}

The authors would like to thank Mr. H. Lekeux, Mr. J., Stallaert, Mr. J. Van Eeckhoudt, Ms. E. Bellefroid and Mr. F. Van Caekenberghe, who are involved in the maintenance of the Rubiaceae collection of the National Botanic Garden of Belgium and Mr. J. Sampson, curator of the Manie van der Schijff Botanical Garden, University of Pretoria. This research was supported financially by the Fund for Scientific Research, Flanders (FWO, G.0343.09N). D.V.E. holds a PhD research grant from the Fund for Scientific Research, Flanders (FWO, no. 1.1.722.10.N.00). B.V. holds a $\mathrm{PhD}$ research grant from the Institute for the Promotion of Innovation by Science and Technology in Flanders (IWT, no. 91158). The funders had no role in study design, data collection and analysis, decision to publish, or preparation of the manuscript. 


\section{Reference list}

[1] Botha, C.J., Penrith, M.L., 2008. Poisonous plants of veterinary and human importance in southern Africa. J. Ethnopharm. 119, 549-558.

[2] Kellerman, T.S., 2009. Poisonous plants. Onderstepoort J. Vet. Res. 76, 19-23.

[3] Vahrmeyer, J., 1981. Poisonous plants of Southern Africa that cause stock losses. Tafelberg, Cape Town.

[4] Hurter, L.R., Naudé, T.W., Adelaar, T.F., Smit, J.D., Codd, L.E., 1972. Ingestion of the plant Fadogia monticola Robyns as an additional cause of gousiekte in ruminants. Onderstepoort J. Vet. Res. 39, 71-82.

[5] Kellerman, T.S., Naudé, T.W., Fourie, N., 1996. The distribution, diagnosis and estimated economic impact of plant poisonings and mycotoxicosis in South Africa. Onderstepoort J. Vet. Res. 63, 65-90.

[6] Theiler, A., Du Toit, P.J., Mitchell, D.T., 1923. Gousiekte in sheep. In: $9^{\text {th }}$ and $10^{\text {th }}$ reports of the director of veterinary education and research, Onderstepoort, Pretoria. The Government Printing and Stationary Office.

[7] Adelaar, T.F., Terblanche, M., 1967. A note on the toxicity of the plant Pachystigma thamnus Robyns. J. S. Afr. Vet. Med. Assoc. 38, 25-26.

[8] Kellerman, T.S., Coetzer, J.A.W., Naudé, T.W., 1988. Plant poisonings and mycotoxicoses of livestock in southern Africa. Oxford University Press, Cape Town.

[9] Uys, P.L., Adelaar, T.F., 1957. A new poisonous plant. J. S. Afr. Vet. Med. Assoc. 28, 5-8.

[10] Fourie, N., Erasmus, G.L., Schultz, R.A., Prozesky, L., 1995. Isolation of the toxin responsible for gousiekte, a plant-induced cardiomyopathy of ruminants in southern Africa. Onderstepoort J. Vet. Res. 62, 77-87.

[11] Bode, M.L., Gates, P.J., Gebretnsae, S.Y., Vleggaar, R., 2010. Structure elucidation and stereoselective total synthesis of pavettamine, the causal agent of gousiekte.

Tetrahedron 66, 2026-2036.

[12] Lemaire, B., Van Oevelen, S., De Block, P., Verstraete, B., Smets, E., Prinsen, E., Dessein, S., 2012. Identification of the bacterial endosymbionts in leaf nodules of Pavetta (Rubiaceae). Int. J. Syst. Evol Microbiol. 62, 202-209.

[13] Van Wyk, A.E., Kok, P.D.F., Van Bers, N.L., Van der Merwe, C.F., 1990. Nonpathological bacterial symbiosis in Pachystigma and Fadogia (Rubiaceae): its 
evolutionary significance and possible involvement in the aetiology of gousiekte in domestic ruminants. S. Afr. J. Sci. 86, 93-96.

[14] Verstraete, B., Van Elst, D., Steyn, H., Van Wyk, B., Lemaire, B., Smets, E., Dessein, S., 2011. Endophytic bacteria in toxic South African plants: identification, phylogeny and possible involvement in gousiekte. PLoS ONE

6(4):e19265.doi10.1371/journal.pone.0019265

[15] Van Elst, D., van Wyk, B., Schultz, A., Prinsen, E., 2013. Production of toxic pavettamine and pavettamine conjugates in the gousiekte-causing Fadogia homblei plant and its relation to the bacterial endosymbiont. Phytochem. 85, 92-98.

[16] Kellerman, T.S., Coetzer, J.A.W., Naudé, T.W., Botha, C.J., 2005. Plant poisonings and mycotoxicoses of livestock in southern Africa, $2^{\text {nd }}$ ed. Oxford University Press, Cape Town.

[17] Davis, A.P., Govaerts, R., Bridson, D.M., Ruhsam, M., Moat, J., Brummitt, N.A., 2009. A global assessment of distribution, diversity, endemism and taxonomic effort in the Rubiaceae. Ann. Missouri Bot. Gard. 96, 68-78.

[18] Robbrecht, E., 1988. Tropical woody Rubiaceae. Opera Bot. Belg. 1, 1-271.

[19] Bridson, D.M., 2003. Pavetta L. In: G.V. Pope (ed.), Flora Zambesiaca 5(3): 544598. Royal Botanic Gardens, Kew for Flora Zambesiaca Managing Committee, London.

[20] Kok, P.D.F., Grobbelaar, N., 1984. Studies on Pavetta (Rubiaceae) II. Enumeration of species and synonymy. S. Afr. J. Bot 3, 185-187.

[21] Bremer, B., Eriksson, T., 2009. Time tree of Rubiaceae: phylogeny and dating the family, subfamilies, and tribes. Int. J. Plant Sci. 170, 766-793.

[22] Kusano, T., Berberich, T., Tateda, C., Takahashi, Y., 2008. Polyamines: essential factors for growth and survival. Planta 228, 367-381.

[23] Brown, K., 2007. Poisonous plants, pastoral knowledge and perceptions of environmental change in South Africa, c. 1880-1940. Environment and History 13, 307332.

[24] Lawrence, J.A., Foggin, C.M., Prozesky, L., 2010. Gousiekte in African buffalo (Syncerus caffer). J. S. Afr. Vet. Assoc. 81, 170-171.

[25] Naudé, T.W., Kellerman, T.S., Coetzer, J.A.W., 1996. Plant poisonings and mycotoxicoses as constraints in livestock production in East Africa: the southern African experience. J. S. Afr. Vet. Assoc. 67, 8-11. 
[26] Coates Palgrave, M., 2005. Keith Coates Palgrave trees of southern Africa, $3^{\text {rd }}$ edition, $2^{\text {nd }}$ impression. Struik Publishers, Cape Town.

[27] Van Wyk, B., Van den Berg, E., Coates Palgrave, M., Jordaan, M., 2011. Dictionary of names for southern African trees. Briza Publications, Pretoria.

[28] Miller, I.M., 1990. Bacterial leaf nodule symbiosis. Adv. Bot. Res. 17, 163-243.

[29] Lemaire, B., Robbrecht, E., Van Wyk, B., Van Oevelen, S., Verstraete, B., Prinsen, E., Smets, E., Dessein, S., 2011. Identification, origin and evolution of leaf nodulating symbionts of Sericanthe (Rubiaceae). J. Microbiol. 49, 935-941.

[30] Mühlbach, H.P., 1998. Use of plant cell cultures in biotechnology. Biotechnol. Annu. Rev. 4, 113-176.

[31] Smetanska, I., 2008. Production of secondary metabolites using plant cell cultures. Adv. Biochem. Engin./Biotechnol. 111, 187-228.

[32] Wilson, S.A., Roberts, S.C., 2012. Recent advances towards development and commercialization of plant cell culture processes for the synthesis of biomolecules. Plant Biotechnol. J. 10, 249-268.

[33] Mustafa, N.R., de Winter, W., van Iren, F., Verpoorte, R., 2011. Initiation, growth and cryopreservation of plant cell suspension cultures. Nature Protocols 6, 715-742.

[34] Mulabagal, V., Tsay, H ., 2004. Plant cell cultures as a source for the production of biologically important secondary metabolites. Int. J. Appl. Sci. Engin. 2, 29-48.

[35] Galston, A.W., Sahwney, R.K., 1990. Polyamines in plant physiology. Plant Physiol. 94, 406-410. 


\section{Appendix A. Supplementary data}

Table A.1: Summary of the pavettamine and cadaverine levels detected in leaves of selected plant species. ND not detected. Value in nmol/g fresh weight $(* \mathrm{nmol} / \mathrm{g}$ dry weight) \pm St Error $(\mathrm{N}=5)$.

\begin{tabular}{|c|c|c|c|c|}
\hline Plant name & Accession & $\begin{array}{l}\text { Country of } \\
\text { origin }\end{array}$ & Pavettamine & Cadaverine \\
\hline Canthium sp. & BR-19991637-34 & MDG & ND & ND \\
\hline Canthium sp. & BR-20021621-45 & BUR & ND & $0.52 \pm 0.04$ \\
\hline $\begin{array}{l}\text { Chamaepentas hindsioides var. } \\
\text { hindsioides }\end{array}$ & BR-19981824-18 & KEN & ND & ND \\
\hline Coffea arabica & BR-20110273-39 & U & ND & $0.46 \pm 0.03$ \\
\hline Coffea arabica 'Laurina' & BR-19073828 & $\mathrm{U}$ & ND & $0.22 \pm 0.02$ \\
\hline Coffea stenophylla & BR-19370053 & RDC & ND & ND \\
\hline Empogona kirkii & BR-19761052 & ZIM & ND & ND \\
\hline Empogona ruandensis & BR-20041442-78 & ZAM & ND & ND \\
\hline Fadogia homblei $^{\mathrm{a}, \mathrm{c}}$ & Wild collection & S-AFR & $296 \pm 47^{*}$ & $\begin{array}{r}26.19 \pm \\
0.68^{*}\end{array}$ \\
\hline Ixora borboniae & BR-20040313-16 & $U$ & ND & ND \\
\hline Ixora littoralis & BR-20061292-43 & MDG & ND & $3.58 \pm 1.09$ \\
\hline Keetia venosa & BR-19981830-24 & KEN & ND & $0.23 \pm 0.01$ \\
\hline Multidenta sp. & BR-20090139-81 & U & ND & $1.23 \pm 0.11$ \\
\hline Pavetta australiensis & BR-20070326-56 & U & ND & ND \\
\hline Pavetta bowkeri ${ }^{b}$ & PRU & S-AFR & ND* & ND* \\
\hline Pavetta gardeniifolia "cripple" d & PRU & S-AFR & ND* & ND* \\
\hline Pavetta gardeniifolia ${ }^{b}$ & PRU & S-AFR & ND* & ND* \\
\hline Pavetta harborii $^{\mathrm{b}}$ & Wild collection & S-AFR & $1284 \pm 68^{*}$ & $\begin{array}{r}26.03 \pm \\
0.66^{*}\end{array}$ \\
\hline Pavetta lanceolata ${ }^{b}$ & PRU & S-AFR & ND* & ND* \\
\hline Pavetta radicans ${ }^{b}$ & BR-20041440-76 & ZAM & ND & $36.49 \pm 0.56$ \\
\hline Pavetta schumanniana ${ }^{b}$ & BR-20001942-57 & RDC & $1381 \pm 79$ & $14.24 \pm 1.46$ \\
\hline Pavetta schumanniana $^{b}$ & BR-20041430-66 & ZAM & $230 \pm 18$ & $19.26 \pm 5.57$ \\
\hline Pavetta sp. & BR-20001948-63 & RDC & ND & ND \\
\hline Pavetta sp. ${ }^{b}$ & BR-20060123-38 & $U$ & $4135 \pm 121$ & $\begin{array}{r}195.61 \pm \\
4.89\end{array}$ \\
\hline Pavetta sp. ${ }^{b}$ & BR-20121181-83 & $\mathrm{U}$ & ND & $0.11 \pm 0.01$ \\
\hline Pavetta ternifolia & BR-20091161-36 & BUR & ND & $0.12 \pm 0.03$ \\
\hline Pavetta ternifolia & BR-2002160529 & BUR & ND & $0.17 \pm 0.01$ \\
\hline Pavetta zeyheri $^{\mathrm{b}}$ & BR-19951298-47 & S-AFR & ND & ND \\
\hline Pavetta zeyheri $^{\text {b }}$ & PRU & S-AFR & ND* & ND* \\
\hline Phyllopentas schimperi & BR-20021606-30 & BUR & ND & $0.17 \pm 0.03$ \\
\hline Psychotria abouabouensis & BR-19951166-12 & GUI-BIS & ND & ND \\
\hline Psychotria bidentata & BR-19981002-69 & GUI-BIS & ND & $2.11 \pm 0.16$ \\
\hline Psychotria brachyanthoides $^{b}$ & BR-20090445-96 & IVO-COA & ND & $0.62 \pm 0.02$ \\
\hline Psychotria brasiliensis & BR-19074229 & $U$ & ND & ND \\
\hline
\end{tabular}




\begin{tabular}{|c|c|c|c|c|}
\hline Psychotria calva ${ }^{b}$ & BR-20071302-62 & $U$ & ND & $\begin{array}{r}0.080 \pm \\
0.005 \\
\end{array}$ \\
\hline Psychotria calva ${ }^{\mathrm{b}}$ & BR-19620512 & $U$ & ND & $\begin{array}{r}0.048 \pm \\
0.003 \\
\end{array}$ \\
\hline Psychotria carthagenensis & BR-19842833 & PAR & ND & ND \\
\hline Psychotria cf kirkii ${ }^{\text {b }}$ & BR-20001943-58 & RDC & $5172 \pm 513$ & $0.71 \pm 0.09$ \\
\hline Psychotria dorotheae & BR-20081584-62 & GUI & ND & $0.20 \pm 0.02$ \\
\hline Psychotria eminiana & BR-20041446-82 & ZAM & ND & $0.12 \pm 0.01$ \\
\hline Psychotria humilis $^{b}$ & BR-20091359-40 & CAM & ND & $71.70 \pm 5.44$ \\
\hline Psychotria kikwitensis ${ }^{b}$ & BR-20041451-87 & ZAM & ND & $2.65 \pm 0.61$ \\
\hline Psychotria kirkii $^{b}$ & BR-20070328-58 & $U$ & $1352 \pm 156$ & $4.11 \pm 1.22$ \\
\hline Psychotria kirkii $^{b}$ & BR-20010513-92 & $U$ & $551 \pm 21$ & $1.26 \pm 0.06$ \\
\hline Psychotria kirkii $^{b}$ & BR-19761893 & $U$ & $414 \pm 31$ & $1.75 \pm 0.06$ \\
\hline Psychotria kirkii $^{b}$ & BR-19750521 & RDC & $3660 \pm 151$ & $1.55 \pm 0.05$ \\
\hline Psychotria kirkii $^{b}$ & BR-19951273-22 & $U$ & $3116 \pm 101$ & $6.95 \pm 0.11$ \\
\hline Psychotria kirkii $^{b}$ & BR-20021526-47 & $\mathrm{U}$ & $1644 \pm 118$ & $9.61 \pm 0.50$ \\
\hline Psychotria kirkii $^{b}$ & BR-20021203-15 & $U$ & $3330 \pm 226$ & $6.28 \pm 0.24$ \\
\hline Psychotria kirkii $^{b}$ & BR-20070330-60 & $U$ & $2095 \pm 272$ & $1.66 \pm 0.62$ \\
\hline Psychotria kirkii $^{b}$ & BR-20001946-61 & RDC & $2005 \pm 79$ & $5.77 \pm 0.29$ \\
\hline Psychotria kirkii var. hirtella ${ }^{b}$ & BR-20001036-24 & $\mathrm{U}$ & $8674 \pm 1124$ & $2.08 \pm 0.64$ \\
\hline $\begin{array}{l}\text { Psychotria kirkii var. } \\
\text { nairobiensis }{ }^{\mathrm{b}}\end{array}$ & BR-19981825-19 & KEN & $322 \pm 26$ & $2.07 \pm 0.11$ \\
\hline $\begin{array}{l}\text { Psychotria kirkii var. } \\
\text { tarambassica }\end{array}$ & BR-19536779 & $U$ & $1396 \pm 219$ & $3.07 \pm 0.91$ \\
\hline Psychotria linearisepala & BR-20041448-84 & ZAM & ND & ND \\
\hline Psychotria loniceroides & BR-19951089-32 & AUS & ND & ND \\
\hline Psychotria lucens var lucens & BR-19610404 & $U$ & ND & $0.20 \pm 0.02$ \\
\hline Psychotria micrantha & BR-20070327-57 & $U$ & ND & $0.37 \pm 0.03$ \\
\hline Psychotria nervosa & BR-20070329-59 & CUBA & ND & $0.18 \pm 0.02$ \\
\hline Psychotria peduncularis & BR-20041438-74 & ZAM & ND & ND \\
\hline Psychotria poliostemma & BR-20071202-59 & $U$ & ND & ND \\
\hline Psychotria pumila var. pumila ${ }^{b}$ & BR-20041435-71 & ZAM & ND & ND \\
\hline Psychotria rubra & BR-20071083-37 & TAI & ND & $0.21 \pm 0.01$ \\
\hline Psychotria rufipilis & BR-19951167-13 & GUI-BIS & ND & $28.12 \pm 2.28$ \\
\hline Psychotria serpens & BR-19981655-43 & JAP & ND & ND \\
\hline Psychotria sp. & BR-20041429-65 & ZAM & ND & ND \\
\hline Psychotria sp. & BR-19991670-67 & MDG & ND & $0.54 \pm 0.02$ \\
\hline Psychotria sp. & BR-20040506-15 & RDC & ND & ND \\
\hline Psychotria sp. & BR-19880538 & MDG & ND & ND \\
\hline Psychotria sp. $^{b}$ & BR-20001933-48 & RDC & $4084 \pm 174$ & $6.25 \pm 0.29$ \\
\hline Psychotria succulenta & BR-20041444-80 & ZAM & ND & $0.40 \pm 0.01$ \\
\hline Psychotria thonneri & BR-20091423-07 & $U$ & ND & $0.10 \pm 0.01$ \\
\hline Psychotria verschuerenii var. & BR-19750204 & CAM & ND & $3.74 \pm 0.09$ \\
\hline
\end{tabular}




\begin{tabular}{|c|c|c|c|c|}
\hline reducta ${ }^{b}$ & & & & \\
\hline Psychotria viridiflora ${ }^{b}$ & BR-20070138-62 & $U$ & $1256 \pm 49$ & $6.44 \pm 0.33$ \\
\hline Psychotria vogeliana & BR-20091425-09 & $U$ & ND & $0.11 \pm 0.04$ \\
\hline Psychotria yapoensis & BR-20091323-04 & LIB & ND & $0.21 \pm 0.01$ \\
\hline Tarenna luteola & BR-20041452-88 & ZAM & ND & ND \\
\hline Tricalysia semidecidua & BR-20041439-75 & ZAM & ND & $1.84 \pm 0.15$ \\
\hline Vangueria infausta & BR-20041455-91 & ZAM & ND & $5.77 \pm 0.58$ \\
\hline Vangueria madagascariensis & BR-19764330 & $\mathrm{MOZ}$ & ND & $0.19 \pm 0.06$ \\
\hline Vangueria pygmaea $^{c}$ & Wild collection & S-AFR & $374 \pm 13^{*}$ & $182.9 \pm 7.8^{*}$ \\
\hline Vangueria triflora $^{\mathrm{c}}$ & Wild collection & S-AFR & ND* & ND* \\
\hline
\end{tabular}

${ }^{\mathrm{a}}$ value adopted from Van Elst et al. [15]

${ }^{b}$ species with leaf nodules

${ }^{\mathrm{c}}$ species with non-nodulating bacterial endophytes

d “cripple”: a plant of a nodulated species, but with leaves lacking visible bacterial nodules due to prior treatment to render it "free" from endophytes 